\title{
Factors Limiting Adaptation to Climate Change among Farmers in Taraba State, Nigeria
}

\author{
Mbah, E.N. ${ }^{\circledR}$ \\ Nwunuji, R. ${ }^{2}$ \\ 1.2Department of Agricultural Extension and Communication, University of Agriculture, Makurdi, Nigeria
}

\begin{abstract}
The study was carried out in Taraba State, Nigeria to identify factors limiting adaptation to climate change among farmers. Questionnaire/interview schedule was used to collect data from a sample of 90 respondents used for the study. Data were analyzed using frequency, percentage, mean scores and standard deviation. Results show that radio $(72.2 \%)$ and fellow farmers $(58.9 \%)$ were major sources of information on climate change available to farmers. Effects of climate change were reduces body weight of livestock (M $=2.80)$, causes stunted growth of crops $(\mathrm{M}=2.77)$, reduction in farm income/revenue $(\mathrm{M}=2.61)$, increases pests/diseases infestation $(\mathrm{M}=2.46)$, late fruiting of fruit trees $(\mathrm{M}$ $=2.41)$, drying of seedlings after germination and transplanting $(\mathrm{M}=2.39)$, drying of streams/rivers $(M=2.38)$, low yield of crop/crop failure $(M=2.33)$, reduces feed intake of livestock $(\mathrm{M}=2.31)$, easy loss of water from the soil $(\mathrm{M}=2.31)$, among others. Major constraints to climate change adaptation measures include poor access to information relevant to adaptation $(M=3.68)$, inadequate financial resources $(M=3.51)$, high cost of farm inputs such as fertilizer $(\mathrm{M}=3.50)$, poverty $(\mathrm{M}=3.31)$, limited access to improved livestock breeds $(M=3.29)$, high cost of improved crop varieties $(M=3.27)$, lack of access to weather forecast $(\mathrm{M}=3.21)$, lack of access to improved crop varieties $(\mathrm{M}=$ 3.21 ), etc. The study recommends the need for relevant agencies such as meteorological agencies and other government agencies to employ the use of mass media such as radio and/or television in disseminating information on climate change effects and mitigation strategies to farmers and highlights that efforts of the Nigerian government is highly needed in providing farm inputs such as fertilizer, improved seeds and chemicals to small-scale farmers at subsidized rate and at appropriate time through a well-coordinated system in order to boost productivity.
\end{abstract}

Keywords: Climate change, Adaptation, Effects, Constraints, Farmers, Nigeria.

\section{Introduction}

Climate change is perhaps the most serious environmental threat facing mankind worldwide [1]. It affects agriculture in several ways, one of which is its direct impact on food production. Climate is the primary determinant of agricultural productivity [2,3].

United Nations Development Programme UNDP [4] defines climate change as a change which is attributed directly or indirectly to human activity, that alters the composition of global atmosphere and which is in addition to natural climate variability observed over comparable time periods.

According to Hannah, et al. [5] climate change refers to short, medium and long-term changes in weather patterns and temperature that are predicted to happen, or are already happening as a result of anthropogenic emission of greenhouse gases such as carbon dioxide.

These changes include a higher frequency of extreme weather events such as drought and floods, as well as greater unpredictability and variability in the seasons of rainfall.

Given the fundamental role of agriculture in human welfare, concern has been expressed by federal agencies and other regarding the potential effect and/or consequences of climate change on agricultural productivity. Climate change is expected to affect crop and livestock production, hydrologic balances, input supplies and other components of agricultural systems [2]. 
Lack of funds hinders small-scale farmers from getting the necessary resources and technologies. However, lack of information to adaptation options could be attributed to the fact that researches on climate change and adaptation options have not been strengthened in the country hence, information is lacking in this area.

The fact that adaptation strategies are costly [6] makes farmers vulnerable to the negative effects of climate change.

This cost could be revealed through the need for intensive labour use. Thus, if farmers do not have sufficient family labour or the financial means to hire labour, they cannot adopt easily to climate change. Adebayo [7] reported that the most adverse effects of climate change and felt mainly by developing countries, especially those in Africa due to their low level of coping capabilities [1,8].

It is noted by International Fund for Agriculture and Development International Fund and Agriculture and Development IFAD [9] that the capacity of local communities to adapt to climate change and mitigate its impacts will also depend on their socio-economic and environmental conditions, and on the available resources. Climate change in Nigeria especially Taraba state is accompanied by variability in rainfall and temperature.

Higher temperature increases moisture stress on crops directly by increasing evapotranspiration as well as atmospheric holding capacity for water vapour. Indirectly, higher temperature causes breakdown of organic matter, culminating in less moisture retention and additional crop moisture stress.

Plants in early stages of development are especially vulnerable to extreme weather, for example, temperatures greater than $30^{\circ} \mathrm{C}$ cause corn pollens to loss viability, while temperatures higher than $20^{\circ} \mathrm{C}$ depress tuber initiation and bulking in potato [10]. The risk of agricultural losses due to pests infestation may also increase as a result of climate change. This is likely to be brought about in changes in the distribution of weeds, insects and plant diseases [10]. This raises the following pertinent questions.

i. What are sources of information on climate change among farmers?

ii. What are effects of climate change?

iii. What are constraints to adaptation to climate change?

Specifically, the study sought to:

i. identify sources of information on climate change;

ii. ascertain effects of climate change; and

iii. ascertain constraints to adaptation to climate change.

\section{Methodology}

The study was carried out in Taraba state, Nigeria. Taraba state was created in 1991 from the Southwestern part of former Gongola State. It is one of the states that make up the North East geographical zone of Nigeria.

It shares interstate borders with Bauchi and Gombe states to the north, Adamawa State to the East, and Benue, Nasarawa, and Plateau States to the west. Its southern boundary is shared with Cameroon. Taraba state covers an area of 60,291.8 square kilometres $\left(\mathrm{km}^{2}\right)$ and lies at latitude $8^{\circ} 00^{\prime}$ North and longitude 10 $10^{\circ}$ ' east.

It has a population of approximately 2,300,736 [11] with a population density of 27 people per square kilometer. The state accounts for $1.6 \%$ of Nigeria's population. The inhabitants of Taraba state are the Jukuns. Major ethnic groups are the Jukuns, Mambila, Fulani, Keteb, Mumuye, Jenjo, Wukum, Ichen, Tiv, Kaka, Hausa and Ndoro.

Agriculture is the state's main economic activity. Coffee, tea, groundnut, cotton, maize, rice, sorghum, millet, cassava and yam are all produced in commercial quantities. Taraba State is home to West Africa's only highland tea plantation.

Cattle, sheep and goats are all reared in large numbers on the Mambila, Plateau. Poultry production, rabbit breeding and pig farming are practiced on a fairly large scale. The state has three (3) agricultural zones namely, northern, north central and southern. Southern Zone was selected purposively for the study which comprises five (5) blocks namely, Ussa, Takum, Dongo, Wukari and Ibi.

Two (2) blocks namely; Ussa and Takum were selected from the five blocks using simple random sampling technique because of its proximity.

Three (3) circles were selected from each of the blocks, totally six (6) circles. Fifteen (15) farmers were selected randomly from each of the circles, giving a total of ninety (90) respondents for the study. Interview schedule/questionnaire was used for data collection. Data were analyzed using descriptive statistics such as frequency, percentage, mean scores and standard deviation.

\section{Results and Discussion}

\subsection{Sources of Information on Climate Change}

Majority $(72.2 \%)$ of the respondents sourced information on climate change from radio, $58.9 \%$ obtained information from fellow farmers, $54.4 \%$ got information from print media such as magazine/newspaper, while $53.3 \%$ and $40.0 \%$ of the respondents sourced information from extension workers and meetings, respectively, among others (Table 1).

This indicates that radio and fellow farmers were major sources of information on climate change. This could be attributed to the fact that radio has a wide network coverage which penetrates easily in rural areas and farmers can as well interact freely among themselves.

This result agrees with Chikwendu, et al. [12] who confirmed that the widely held views that media are important either singly or in combination in the transfer of improved agricultural practices to farmers. 
Table-1. Distribution of respondents according to sources of information on climate change $(\mathrm{n}=90)$

\begin{tabular}{l|c|c}
\hline Sources of information & Frequency & Percentage (\%) \\
\hline Extension agents & 48 & 53.3 \\
\hline Television & 32 & 35.6 \\
\hline Radio & 65 & 72.2 \\
\hline Print media such as magazine, newspaper & 49 & 54.4 \\
\hline Fellow farmers & 53 & 58.9 \\
\hline Meetings & 36 & 40.0 \\
\hline Seminars & 12 & 13.3 \\
\hline Research Institutes & 11 & 12.2 \\
\hline Farm input suppliers & 9 & 10.0 \\
\hline University researchers & 8 & 8.9 \\
\hline Ministry of Agriculture Staff & 12 & 13.3 \\
\hline Internet & 13 & 14.4 \\
\hline * Multiple responses & & \\
\hline
\end{tabular}

* Multiple responses

Source: Field Survey, 2015

\subsection{Effects of Climate Change}

Effects of climate change as indicated by the respondents were reduces body weight of livestock $(\mathrm{M}=2.80)$, causes stunted growth of crops $(\mathrm{M}=2.77)$, reduction in farm income/revenue $(\mathrm{M}=2.61)$, increases pests/diseases infestation $(\mathrm{M}=2.46)$, late fruiting of fruit trees $(\mathrm{M}=2.41)$, drying of seedlings after germination and transplanting $(\mathrm{M}=2.39)$, drying of streams/rivers $(\mathrm{M}=2.38)$, low yield of crop/crop failure $(\mathrm{M}=2.33)$, reduces feed intake of livestock $(M=2.31)$, easy loss of water from the soil $(M=2.31)$, reduces egg size of birds $(M=2.26)$, poor quality of farm produce $(\mathrm{M}=2.26)$, reduces soil fertility $(\mathrm{M}=2.24)$, and reduction in supply of raw materials to agro-based industries $(\mathrm{M}=2.24)$, among others (Table 2$)$.

The standard deviation on the responses of respondents was mostly less than 1 except for one variable whose standard deviation was 2.16 .

This shows the disparity in terms of the responses on effects of climate change.

This implies that climate change brings about reduction in farm output which leads to loss of income among farm families. The finding agrees with Oladipo [13] who noted that agriculture is most sensitive to global warming of climate change and its effects lead to stunted growth of crops, easy spread of pests, diseases attack on crops, livestock and fish, drying of seedlings after germination and transplanting, low yield of crops/crop failure, low quality of farm produce, fall in farm revenues/incomes (economic losses), isolated location of farms, small farm size, low level of technology adoption, reduced supply of raw materials for agro-based industries, impact on water resources and late fruiting of fruit trees.

Table-2. Mean score of respondents on effects of climate change

\begin{tabular}{|c|c|c|}
\hline Effects of climate change & Mean scores & Std Deviation \\
\hline Reduces body weight of livestock & 2.80 & 0.50 \\
\hline Increases pests/diseases infestation & 2.46 & 0.56 \\
\hline Reduces egg size of birds & 2.26 & 0.70 \\
\hline Reduces feed intake of livestock & 2.31 & 0.66 \\
\hline Reduces soil fertility & 2.24 & 0.71 \\
\hline Causes stunted growth of crops & 2.77 & 0.50 \\
\hline Drying of seedlings after germination and transplanting & 2.39 & 0.57 \\
\hline Low yield of crops/crop failure & 2.33 & 0.58 \\
\hline Poor quality of farm produce & 2.26 & 0.59 \\
\hline Reduction in farm income/revenue & 2.61 & 2.16 \\
\hline Reduction in supply of raw materials to agro-based industries & 2.24 & 0.72 \\
\hline Late fruiting of fruit trees & 2.41 & 0.67 \\
\hline Drying of streams/rivers & 2.38 & 0.61 \\
\hline Easy loss of water from the soil & 2.31 & 0.66 \\
\hline Economic poverty of ruralities & 2.32 & 0.60 \\
\hline Sale of assets such as land & 2.01 & 0.74 \\
\hline Increases hunger/famine among family members & 2.41 & 0.65 \\
\hline Food insecurity in household & 2.31 & 0.70 \\
\hline Migration to urban areas & 2.24 & 0.69 \\
\hline Unemployment & 2.38 & 0.63 \\
\hline Insecurity of livelihood & 2.24 & 0.74 \\
\hline Dependency on food aids & 2.07 & 0.76 \\
\hline Increases vulnerability to soil erosion & 2.23 & 0.67 \\
\hline Water logging of farmland & 2.31 & 0.68 \\
\hline Loss of biodiversity & 2.04 & 0.75 \\
\hline Increases risk of flooding & 2.34 & 0.70 \\
\hline Difficulty in forest regeneration & 2.42 & 0.70 \\
\hline \multicolumn{3}{|l|}{ Changes in dates of onset of rainy } \\
\hline season/change in rainfall pattern & 2.13 & 0.80 \\
\hline Desertification & 2.28 & 0.67 \\
\hline Worsening soil condition & 2.43 & 0.67 \\
\hline
\end{tabular}




\subsection{Constraints to Climate Change Adaptation Measures}

Major constraints to climate change adaptation measures include poor access to information relevant to adaptation $(M=3.68)$, inadequate financial resources $(M=3.51)$, high cost of farm inputs such as fertilizer $(M=$ 3.50), poverty ( $\mathrm{M}=3.31)$, limited access to improved livestock breeds $(\mathrm{M}=3.29)$, high cost of improved crop varieties $(\mathrm{M}=3.27)$, lack of access to weather forecast $(\mathrm{M}=3.21)$, lack of access to improved crop varieties $(\mathrm{M}=$ 3.21), non-availability of storage facilities $(M=3.19)$, and poor extension agent contact $(M=3.18)$, among others (Table 3).

Most of the standard deviation on constraints to climate change adaptation measures was less than 1, while a few others were 1 and above. This shows the disparities on the responses of the respondents.

This implies that the respondents were highly constrained by economic factors in adapting to climate change. This agrees with International Fund and Agriculture and Development IFAD [9] who noted that the capacity for local communities to adapt to climate change and mitigate its impacts will also depend on their socio-economic and environmental conditions, and on the available resources.

Table-3. Mean score of constraints to climate change adaptation measures

\begin{tabular}{|c|c|c|}
\hline Constraints & Mean score & Std deviation \\
\hline Poor access to information relevant to adaptation & 3.68 & 0.72 \\
\hline Inadequate financial resources & 3.51 & 1.03 \\
\hline Poor extension agent contact & 3.18 & 0.82 \\
\hline Lack of access to weather forecasts & 3.21 & 0.81 \\
\hline Lack of access to improved crop varieties & 3.21 & 0.79 \\
\hline Limited access to improved livestock breeds & 3.29 & 0.74 \\
\hline High cost of improved crop varieties & 3.27 & 0.80 \\
\hline Non-availability of storage facilities & 3.19 & 0.81 \\
\hline Limited knowledge on adaptation measures & 3.32 & 0.75 \\
\hline $\begin{array}{l}\text { Government inability to respond/come to aid of people affected with climate } \\
\text { change such as flood }\end{array}$ & 3.00 & 1.03 \\
\hline High cost of farm inputs such as fertilizer & 3.50 & 0.55 \\
\hline High cost of irrigation facilities & 3.51 & 0.69 \\
\hline Non-availability of modern farm inputs & 3.21 & 0.81 \\
\hline Non-availability of modern processing facilities & 3.19 & 0.90 \\
\hline Unavailability of farm labour & 3.09 & 0.82 \\
\hline High cost of farm labour & 3.33 & 0.76 \\
\hline Poverty & 3.31 & 0.79 \\
\hline Unavailability of labour saving technologies for easy farming operation & 3.08 & 1.00 \\
\hline
\end{tabular}

\section{Conclusion and Recommendations}

Major sources of information on climate change in the study area were radio and fellow farmers. This could be attributed to the fact that radio has a wide network coverage which can penetrate easily in rural areas.

Climate change effects were mostly observed in the following areas: reduced body weight of livestock, causes stunted growth of crops, reduction in farm income, increases pests/diseases infestation, late fruiting of fruit trees, among others.

The respondents were highly constrained to climate change adaptation measures by economic factors such as inadequate financial resources, high cost of farm inputs, poverty, limited access to improved livestock breeds, high cost of improved crop varieties, among others.

There is need for relevant agencies such as meteorological agencies and other government agencies to employ the use of mass media such as radio and/or television in disseminating information on climate change effects and mitigation strategies to farmers.

Farm inputs such as fertilizer, improved seeds and agro-chemicals should be made available to small-scale farmers at subsidized rate and at appropriate time through a well-coordinated system. This will help to overcome the challenges faced by the respondents.

\section{References}

[1] J. C. Nwafor, "Global climate change: The driver of multiple causes of flood intensity in Sub-Saharan Africa," presented at the Paper Presented at the International Conference on Climate Change and Economic Sustainability Held at Nnamdi Azikiwe University, Awka, Nigeria, 2007.

[2] R. M. Adams, B. R. Hurd, S. Lenhart, and N. Leary, "Effects of global climate change on agriculture: An interpretative review," Climate Research, vol. 11, pp. $19-30,1998$.

[3] A. Cumhur and M. S. Cresser, "The effects of global climate change on agriculture," American Eurasian J. Agric. and Environ. Sci., vol. 3, pp. $672-676,2008$.

[4] United Nations Development Programme UNDP, "Human development report 2007/2008," Fighting Climate Change: Human Solidarity in a Divided World New York, 2007.

[5] R. Hannah, A. Mozaharul, B. Rachael, C. Terry, H. Slaeemul, and M. Angela, Community based adaptation to climate change: An overview. In: Holly, A. Nicole, K., and Angela, M. (Eds). Participatory learning and action. London: The International Institute for Environment and Development IIED, 2009

[6] R. Mendelson and L. Williams, "Comparing forcast of the global impacts of climate change mitigation and adaptation strategies," Global Change, vol. 9, pp. $315-333,2004$.

[7] A. A. Adebayo, "Climate change impact on education," presented at the Paper Presented at the National Conference on Climate Change and Environmental Input on Education, Held at Federal University of Technology, Yola, 2011.

[8] S. Jagtap, "Managing vulnerability to extreme weather and climate events: Implications for agriculture and food security in Africa," in Proceedings of the international Conference on Climate Change and Economic Sustainability Held at Nnamdi Azikiwe University, Awka, Nigeria, 2007, pp. $12-14$.

[9] International Fund and Agriculture and Development IFAD, "Enabling rural poor to overcome poverty," Technical Expert Workshop on Gaps, Trends and Current Research in Gender Dimensions of Agricultural and Rural Employment: Differentiated Pathways Out of Poverty. Rome: Italy, 2009. 
[10] G. M. Paulsen, High temperature responses of crop plants. In: K. J. Bote; Beneth, J. M. Sinclair, T. R. and Paulsen, A. H. (Eds). Physiology and determination and determination of crop yields. Madison WI: America Society of Agronomy, 1994.

$[11] \quad$ National Population Commission NPC, National population census figure. Abuja: NPC, 2006.

[12] D. O. Chikwendu, A. M. Omotayo, J. O. Yusuf, and Z. E. Omenesa, "Effectiveness of extension publications in disseminating information on improved farm practices in Nigeria," Nigeria Journal of Rural Economy and Society, vol. 1, pp. 51 - 56, 2000.

[13] E. Oladipo, "Towards enhancing the adaptive capacity of Nigeria. A review of the country's state of preparedness for climate change adaptation," Report Submitted to Heinrich Boll Foundation Nigeria, 2010.

Citation | Mbah, E.N.; Nwunuji, R. (2016). Factors Limiting Adaptation to Climate Change among Farmers in Taraba State, Nigeria. Agricultural Development, 1: 1-5.

History:

Received: 25 August 2015

Revised: 27 September 2015

Accepted: 10 October 2015
Published: 6 November 2015

Licensed: This work is licensed under a Creative Commons

Attribution 3.0 License $(\mathrm{ccc})$

Publisher: Eastern Centre of Science and Education
Acknowledgement: Both authors contributed to the conception and design of the study.

Funding: This study received no specific financial support.

Competing Interests: The authors declare that they have no conflict of interests.

Transparency: The authors confirm that the manuscript is an honest, accurate, and transparent account of the study was reported; that no vital accurate, and transparent account of the study was reported; that no vital
features of the study have been omitted; and that any discrepancies from the study as planned have been explained.

Ethical: This study follows all ethical practices during writing.

Eastern Centre of Science and Education is not responsible or answerable for any loss, damage or liability, etc. caused in relation to/arising out of the use of the content. Any queries should be directed to the corresponding author of the article. 